\title{
Vulnerability Assessment Using Raster Calculation and DRASTIC Model for the Jordan Valley Subsurface Basin (AB1) Imaging Maps
}

\author{
Atallah M. Al-Shatnawi', Rabah Al-Shboul'2, Bader M. Al-Fawwaz ${ }^{1}$, Wafa Al-Sharafat' ${ }^{1}$, \\ Refaat M. Bani Khalf ${ }^{3}$ \\ ${ }^{1}$ Department of Information Systems, Al-albayt University, Mafraq, Jordan \\ ${ }^{2}$ Department of Computer Sciences, Al-albayt University, Mafraq, Jordan \\ ${ }^{3}$ Water Authority of Jordan, Amman, Jordan \\ Email: atallah@aabu.edu.jo, refaat waj@hotmail.com
}

Received 26 August 2014; revised 25 September 2014; accepted 20 October 2014

Copyright (C) 2014 by authors and Scientific Research Publishing Inc.

This work is licensed under the Creative Commons Attribution International License (CC BY). http://creativecommons.org/licenses/by/4.0/

\section{(c) (i) Open Access}

\section{Abstract}

The vulnerability to pollution of the area between Wadi Shueib and the Dead Sea in the Jordan Valley (AB1) subsurface basis was assessed and evaluated using raster calculation and DRASTIC model for imaging maps in this research. The seven DRASTIC model parameters are: Depth to water, net Recharge, Aquifer media, Soil media, Topography, Impact of vadose zone and Hydraulic conductivity. The seven variables are evaluated by the rating and the weighting numerical indexes. The vulnerability parameters are categorized depending on a fixed interval of suburban area percentage. It showed that the ABI Subsurface was categorized by high vulnerability classes while the middle and western parts were categorized by high to extreme vulnerability classes. The southern part of the AB1 displayed low aquifer vulnerability. The vulnerability map shows the high risk suffered by the middle and western parts of the AB1 Subbasin due to the high possibility pollution of intensive fruit and vegetable cultivation.

\section{Keywords}

Aquifer Vulnerability, DRASTIC, Imaging Map, Dead Sea, Wadi Shueib, Jordan Valley

\section{Introduction}

Groundwater in Jordan and the world is very important resource of water supply because of its relatively low

How to cite this paper: Al-Shatnawi, A.M., et al. (2014) Vulnerability Assessment Using Raster Calculation and DRASTIC Model for the Jordan Valley Subsurface Basin (AB1) Imaging Maps. Journal of Geographic Information System, 6, 585-593. 
susceptibility to contamination (US EPA, 1985). Nevertheless, there are many sources of pollution for aquifers, including agricultural activities. The transfer of these contaminants to groundwater reduces the water quality. Therefore, the purpose of this paper is to assess vulnerability in the area between Wadi Shueib and the Dead Sea in the Jordan Valley (AB1) Subsurface based on the following variables: "Depth to static water, total net Recharge, Aquifer media properties, Soil media properties, Topography patterns, Impact of vadose zone (unsaturated zone), and hydraulic Conductivity (D.R.A.S.T.I.C), which is model of the U.S. environmental protection agency" (EPA, 1985). As well as, this research aims to present the integrated application of DRASTIC and GIS as an active methodology for assessing the groundwater contamination risk and managing the watersheds [1].

DRASTIC is a weighting and rating indices model developed to prepare vulnerability classifications for different sites by combining numerous layers [2]. It was used for manual overlaying of semi-quantitative data themes and the vulnerability index is defined by "a linear combination of factors which shows the feasibility of the computation using GIS" [3]. It is also defined by the following statement: "GIS are designed to manipulate spatial data to represent spatially variable phenomena by applying a series of overlay analysis of data layers that are in spatial register" [3].

A raster image is an array of pixels or cells, arranged in columns and rows, where each pixel has value indicates to useful information. The rasters may are digital pictures, the satellites images or the captured and the scanned maps. Chromatography Term shows the number of colors used in each point which represents both color depth and factors which affect the quality of the images map [4]. The scanned imaging map is this paper's focus. This paper is organized as follows: section 2 presents the study area. Section 3 presents the DRASTIC method and methods of calculating the vulnerability map. Section 4 provides the results and discussion. Finally, the conclusions are presented.

\section{Study Area}

This study area, which is located between Wadi Shueib and the Dead Sea (AB1), is a subsurface basin located in the Western area of the East Banks in the northern side of the Dead Sea as clear in Figure 1. Geographically, the area belongs to the Eastern Mediterranean Basin. It is located in a low point of the Jordan Valley. The center of the AB1 (which is the study area) is located at WGS84 which coordinates to $31^{\circ} 50.362^{\prime} \mathrm{N}$ and $35^{\circ} 36.709^{\prime} \mathrm{E}$ with a total area of about $145 \mathrm{~km}^{2}$ (MWI, 1995).

The study area lies to the south-west of the capital Amman, about $25 \mathrm{~km}$ away. It is located to the north-east of the Dead Sea, and includes the towns of Al Nahda, Rama, Kafrein, Aljild, Jawfet Alkafrein and Alshouneh Aljanobiyya. It is one of the most important agricultural areas in the Central Ghor and is irrigated from of the East Ghor Chanel and Kafrein Dam.

At its widest points, the study area measures $17 \mathrm{~km}^{2}$ from east-west and around $12 \mathrm{~km}$ from north-south. The Basin has high and low points: the AB1 highest point is located in the eastern border with an (MASL) elevation

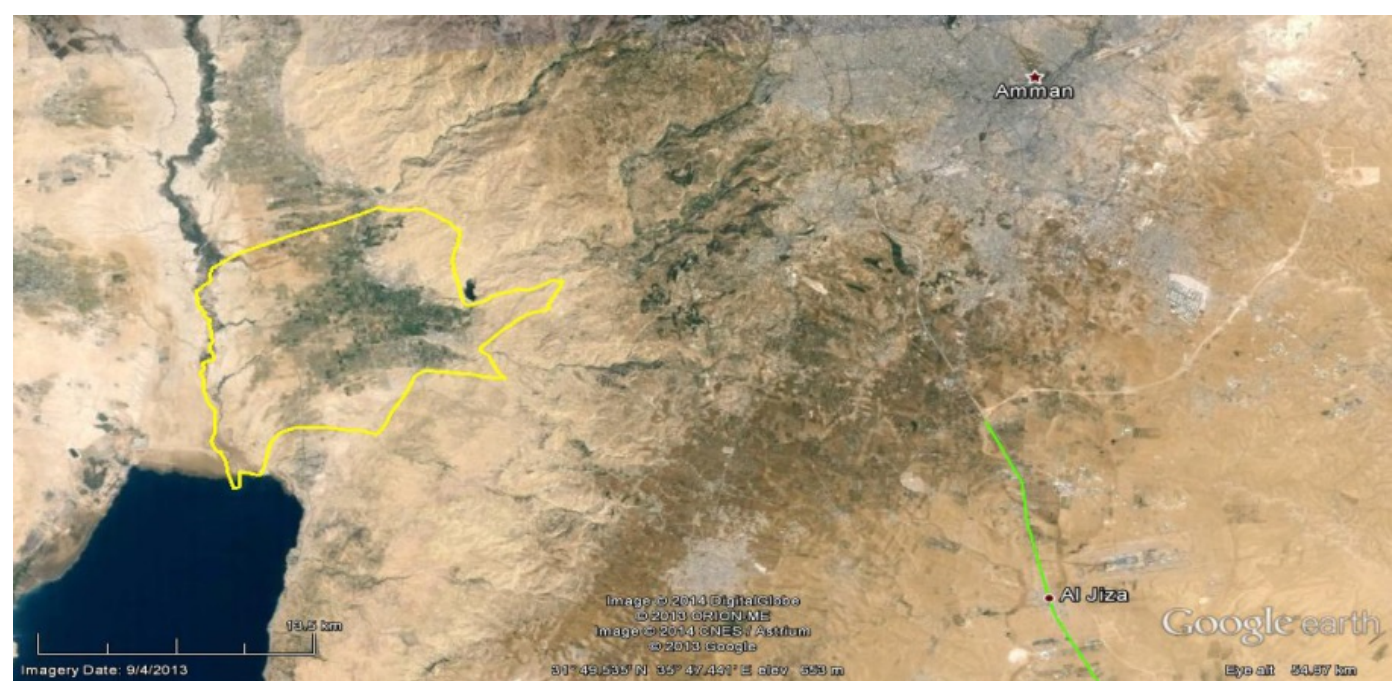

Figure 1. Location of AB1 subsurface basin within Jordan Map [5]. 
of $176 \mathrm{~m}$ above sea level. While the lowest point is located on Wadi Kafrein Dam next to a water reservoir surface, with a (MBSL) elevation of $-415 \mathrm{~m}$ below sea level (MWI, 1995) [6].

\section{Methods}

In this research the Arc Map GIS 10.1 DRASTIC model function is utilized to assess the vulnerability of the AB1 subsurface basin to pollution in general and to groundwater pollution possibility in particular.

\subsection{The DRASTIC Model}

Each character of the DRASTIC acronym refers to one of the following seven DRASTIC model parameters: Depth to water, net Recharge, Aquifer media, Soil media, Topography, Impact of vadose zone and Hydraulic conductivity [7]. The seven parameters are evaluated by two numerical indexes, one referring to rating and one to weight, which are usually gained using the DRASTIC model. The rating index has a very significant impact on each DRASTIC parameter and rating values range from 1 to 10 depending on the impact on aquifer vulnerability. On the other hand, the weight index is calculated with a value ranging from 1 to 5 which reflects the relative importance of each DRASTIC parameter. A linear Equation (1) is used to compute the DRASTIC Index.

$$
\text { DRASTIC Index }=\mathrm{D}_{\mathrm{r}} \mathrm{D}_{\mathrm{w}}+\mathrm{R}_{\mathrm{r}} \mathrm{R}_{\mathrm{w}}+\mathrm{A}_{\mathrm{r}} \mathrm{A}_{\mathrm{w}}+\mathrm{S}_{\mathrm{r}} \mathrm{S}_{\mathrm{w}}+\mathrm{T}_{\mathrm{r}} \mathrm{T}_{\mathrm{w}}+\mathrm{I}_{\mathrm{r}} \mathrm{I}_{\mathrm{w}}{ }^{\dagger}+\mathrm{C}_{\mathrm{r}} \mathrm{C}_{\mathrm{w}}
$$

where D, R, A, S, T, I and C represents the DRASTIC seven parameters respectively. $r$ and $w$ represent the rating and weight [3].

$\mathbf{D}$ is the depth of water, it usually represents the depth that is measured from the top of ground to the static water table, and its weight index is relatively rated at five. $\mathbf{R}$ is the Net Recharge which represents the quantity of water, it infiltrates from the ground surface to the groundwater, and its weight index is relatively rated at four. A is the Aquifer media which refers to the material properties of a given saturated zone, it controls the pollutant reduction procedures, and its weight index is relatively rated at 3. S is the Soil Media which controls the quantity of recharge permeates downward and its weight index is relatively rated at two. $\mathbf{T}$ is the topography which refers to the earth surface slope. It dictates if or not the runoff will stay on the land surface to permit pollutant percolation to the concerned saturated zone, and its weight index is relatively rated at one. I is the Impact of Vadose Zone, the unsaturated zone material, it dominates "the passage and attenuation of the contaminated material to the saturated zone", and its weight index is relatively rated at 5. C is the Hydraulic Conductivity which refers to capability of the aquifer to allow pass on water, thereby determining the rate of transfer of pollutant material through the groundwater aquifer, and its weight index is relatively rated at three [8].

\subsection{Calculating Vulnerability Map}

In this paper, the DRASTIC vulnerability index is obtained of the calculations that are performed using the Equation (1). The vulnerability index is presented by selecting a method that express the mechanism that aquifers expose to pollutants and the degree of hazardous in various area of AB1 Subbasin [9].

Fundamentally, the color codes used in this paper are those colors agreed between users of the DRASTIC model. The indices resultants DRASTIC Colors are categorized through many equal intervals, and each interval is linked with standard color (pseudo colour) that represents the degree of risk and the severity. The vulnerability scores are viewed depending on the ArcMap 10.1 classification system. The vulnerability map are categorized depend on a fixed interval of subbasin area percentage. Vulnerability index values are grouped into the following 5 categories: very low, low, moderate, high and extreme vulnerability. Then the total number of values for each category is shown in the attribute table of vulnerability map. As for vulnerability classification, colour codes are assigned to the percentages of pixels. The blue colours indicate very low vulnerability, the green colour indicates low vulnerability, the yellow colours indicate moderate vulnerability, the orange colour indicates high vulnerability, and finally red indicates extreme vulnerability. The advantage of rating and comparing the colors in the final map is that we are able to study the extent of vulnerable areas, revising land use to minimize the negative effects of risk or environmental hazardous [10].

\section{Results and Discussion}

The results of the seven DRASTIC model parameters of the AB1 Subbasin vulnerability maps are presented and 
discussed in this section.

\subsection{The Depth of Water}

In general the static water table depth in the AB1 Subbasin is shallow (maximum $26 \mathrm{~m}$ ); it decreases from east to west, as the map shows in Figure 2.

According to the map in Figure 2, there are some areas of the study area which display more potential to become contaminated. The rating ranges between 1 and 9 while the maximum scores are located in the northwestern part of the subbasin area (depth to water is $5 \mathrm{~m}$ ).

\subsection{Net Recharge}

The annual rainfall of the AB1 is generally low ( $175 \mathrm{~mm} /$ year max), the total net recharge to the aquifer is organized by land activity and vegetation cover. The lowest recharge average was in Kattar (Jordan River Adjacent Area). The other lands of the AB1 had relatively maximum recharge rates due to irrigation water from Kafrein Dam and East Ghor Canal. The AB1 aquifer has generally medium to extreme net recharge, with rating scores of 8 and 9. The AB1 Subbasin is mostly made up of an alluvium and gravel formation (rating score: 8). The net recharge map is shown in Figure 3.

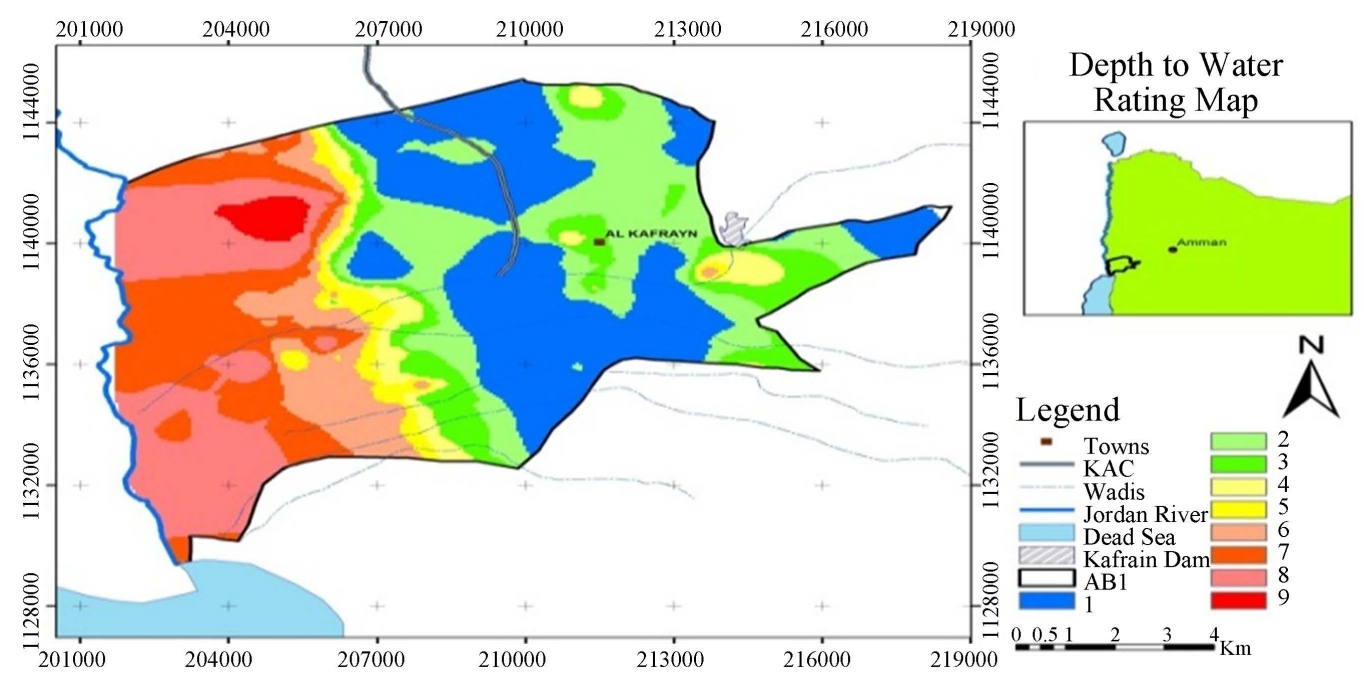

Figure 2. Depth of water rating map.

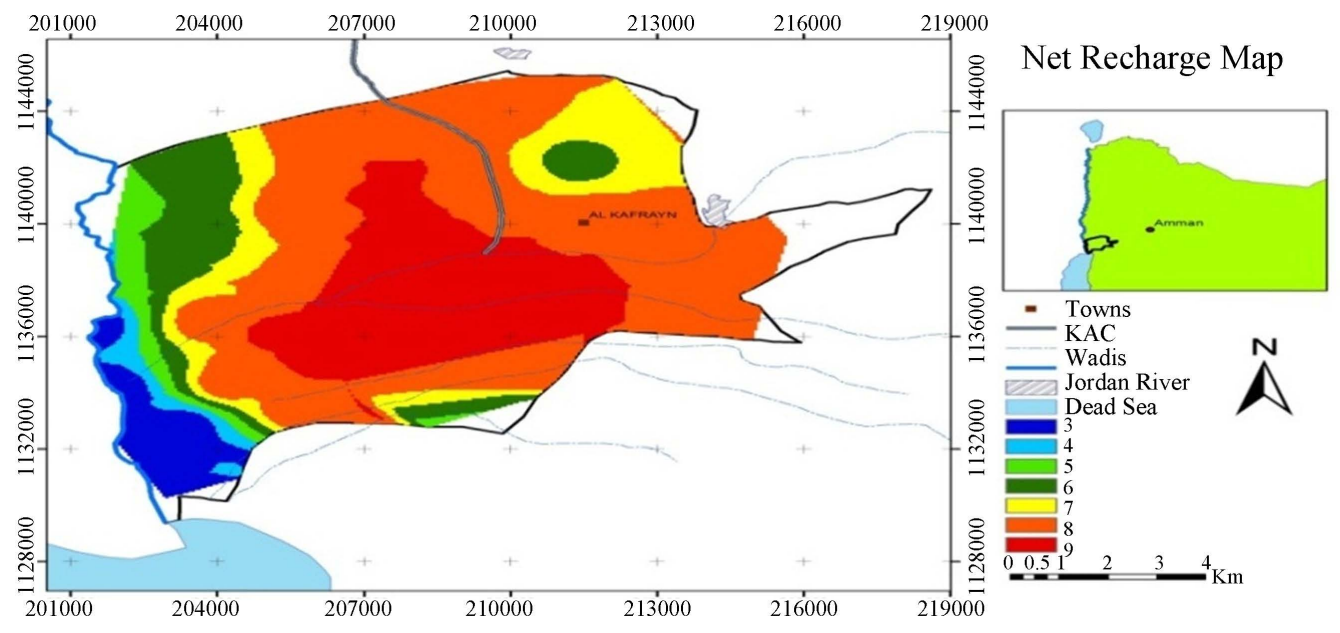

Figure 3. Net recharge map. 


\subsection{Aquifer Media}

A lisan, alluvium and fluviatile formation, along with limestone, is what comprised the majority of the AB1 Subbasin and it obtained a high rating score (8). The Aquifer media map is shown in Figure 4.

\subsection{The Soil Media}

The soil media is usually dynamic. Aridic/ustic and xeric soil are the major types in the AB1Subbasin. The soil kinds were given rates based on their permeability. A score of 9 was assigned to the deeply dissected sandstone escarpment on Kurnub Sandstone, while the minimum score (4) was assigned to the Zohr soil close to Jordan River. The soil media map is shown in Figure 5.

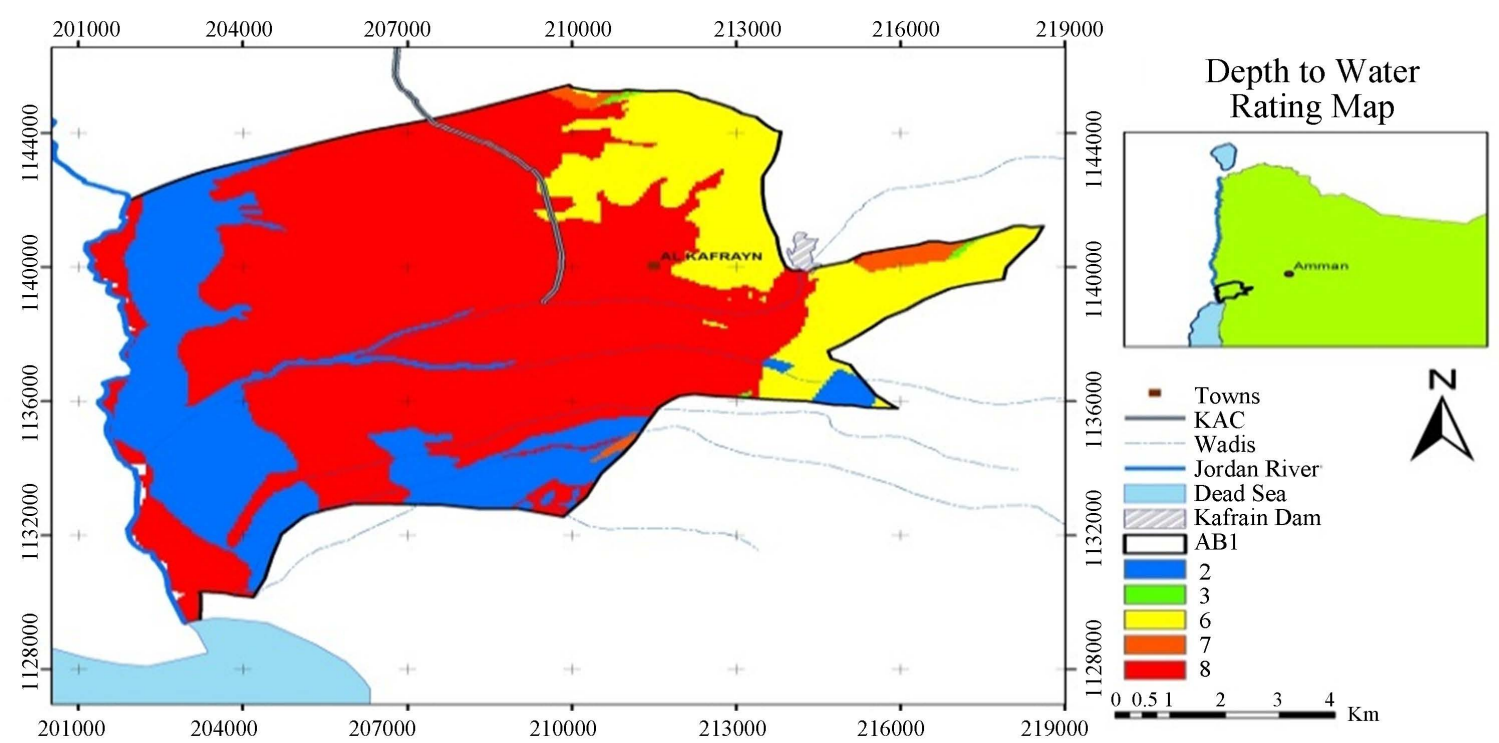

Figure 4. Aquifer media rating map.

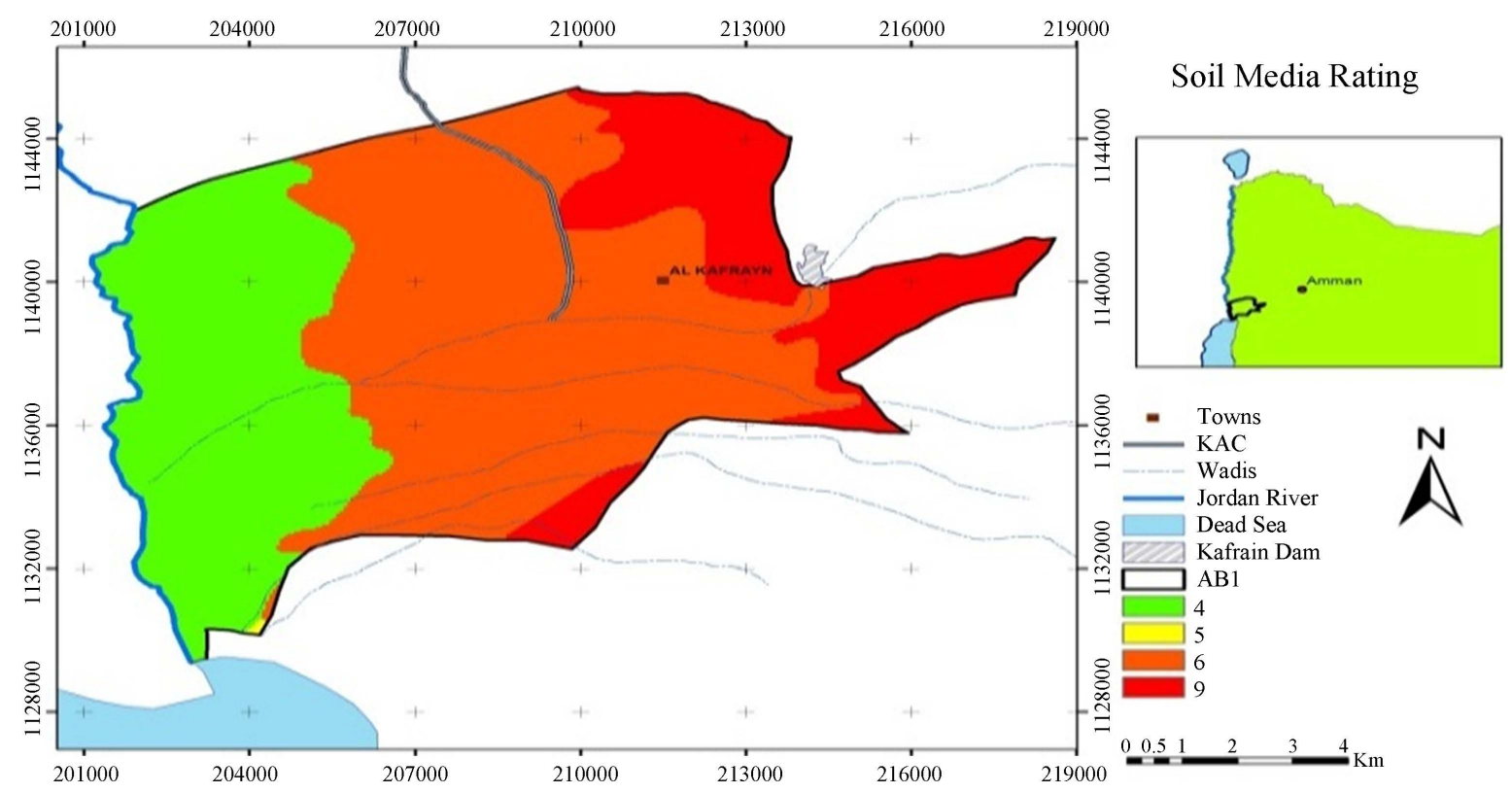

Figure 5. Soil media rating map. 


\subsection{Topography}

The topography displayed a graduated slope over the whole of the AB1 area, which was assigned DRASTIC rating scores ranging start from 1 to 10 . The gradient of the slope increases from east to west of the AB1 Subbasin which associated with Jordan valley plain. The topography rating map is shown in Figure 6.

\subsection{The Impact of Vadose}

The alluvial and gravel obtained a high rating (8), while the sandstone and sand were assigned a moderate score of 6. The lowest rating was 2 for siltstone and schist. The impact of vadose map is shown in Figure 7.

\subsection{Hydraulic Conductivity}

The study area is characterized by moderate values for hydraulic conductivity. Therefore, the maximum rating assigned was a score of 8 . The southwestern area of the AB1 Subbasin has a lower hydraulic conductivity rating,

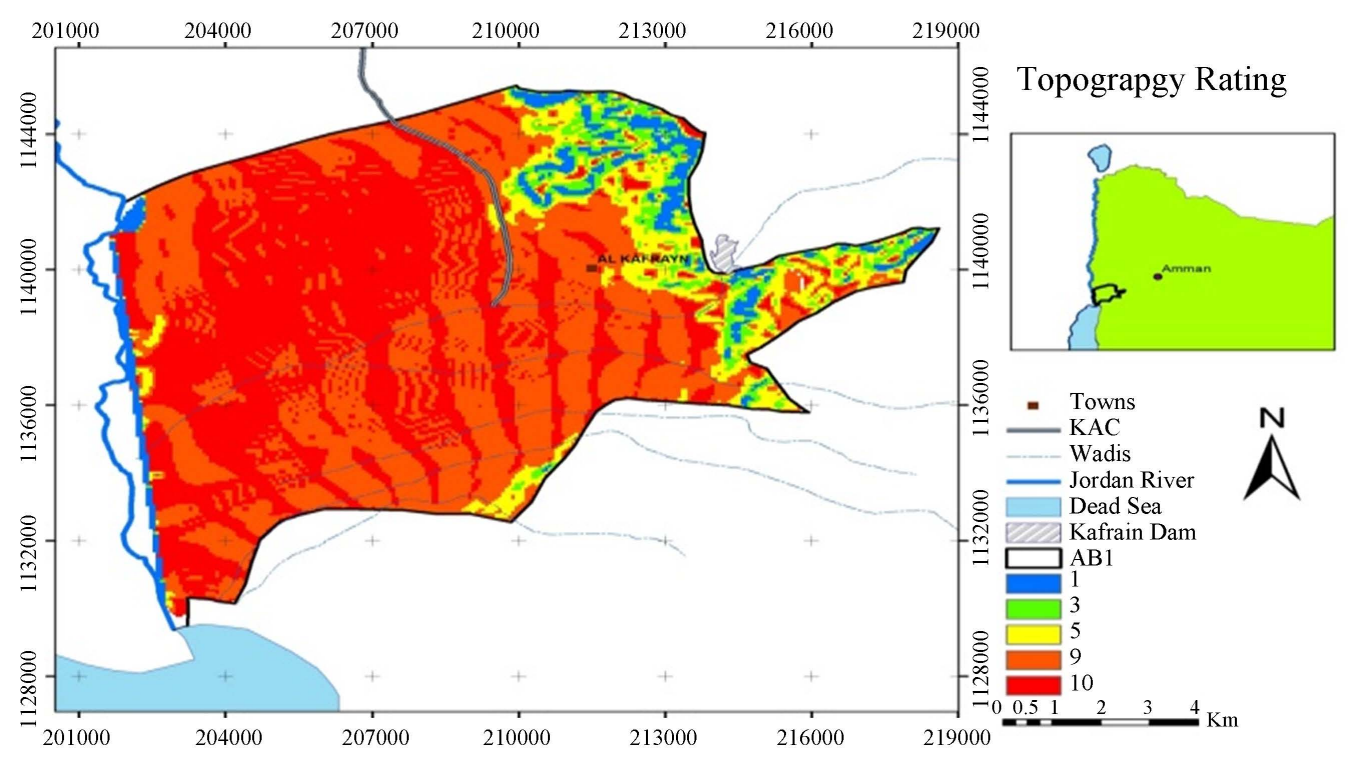

Figure 6. Topography rating map.

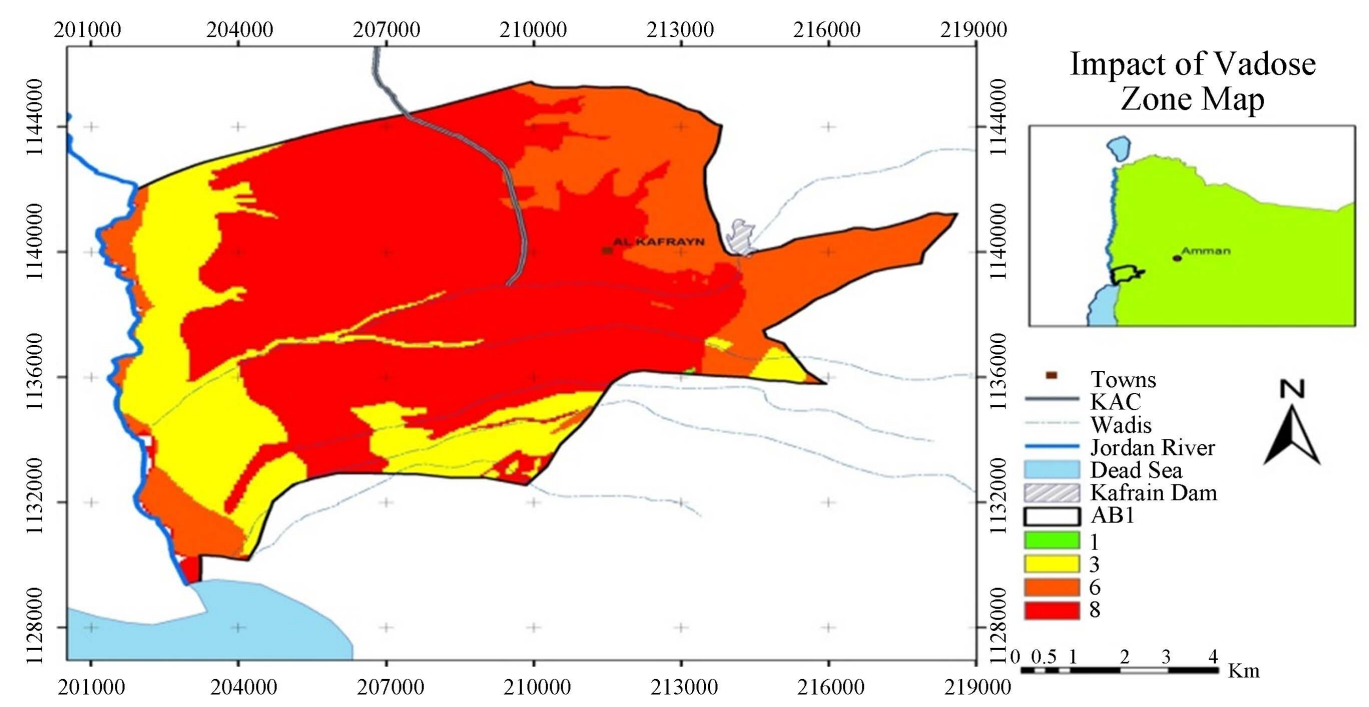

Figure 7. The impact of vadose map. 
with values ranging from 3 to 4 . The hydraulic conductivity map is shown in Figure 8.

\subsection{The Final Vulnerability Map}

The final vulnerability map showed mainly high values (red color) within middle part of AB1 Subbasin heights but the eastern area is described by moderate vulnerability (Yellow), see Figure 9 . This pattern is mainly due to variation in static water level depth from east to west. The southern fragment of the study area shows a low vulnerability. This is because of the mixture of deep static water table, low porosity of vadose layer, variety of groundwater layer media and steep topography. Five categories of vulnerability are presented in AB1 area. The least vulnerable $48 \%$ of the $\mathrm{AB} 1$ is considered agriculturally less important. The final vulnerability map shows that the middle and eastern areas of the AB1 Subbasin are at high risk of pollution. The more vulnerable western areas of the aquifer are at higher risk of contamination because of the high contamination risk related with fruit and vegetable production. Generally speaking, most of the irrigated land of AB1 Subbasin shows high to extreme vulnerability.

From Table 1, we see that the very low vulnerability class accounts for around $10.33 \mathrm{~km}^{2}$ of the total area, while moderate and high vulnerability areas total around $68 \mathrm{~km}^{2}$, this means that most of the AB1 Subbasin is

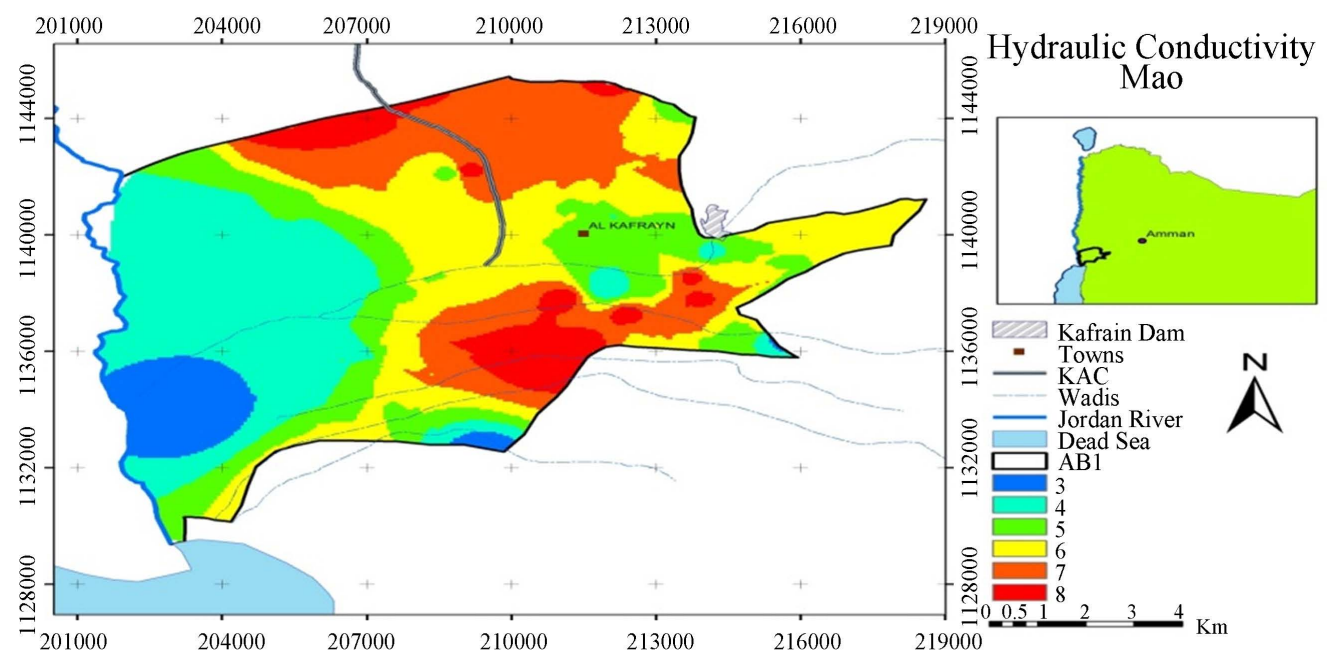

Figure 8. The hydraulic conductivity map.

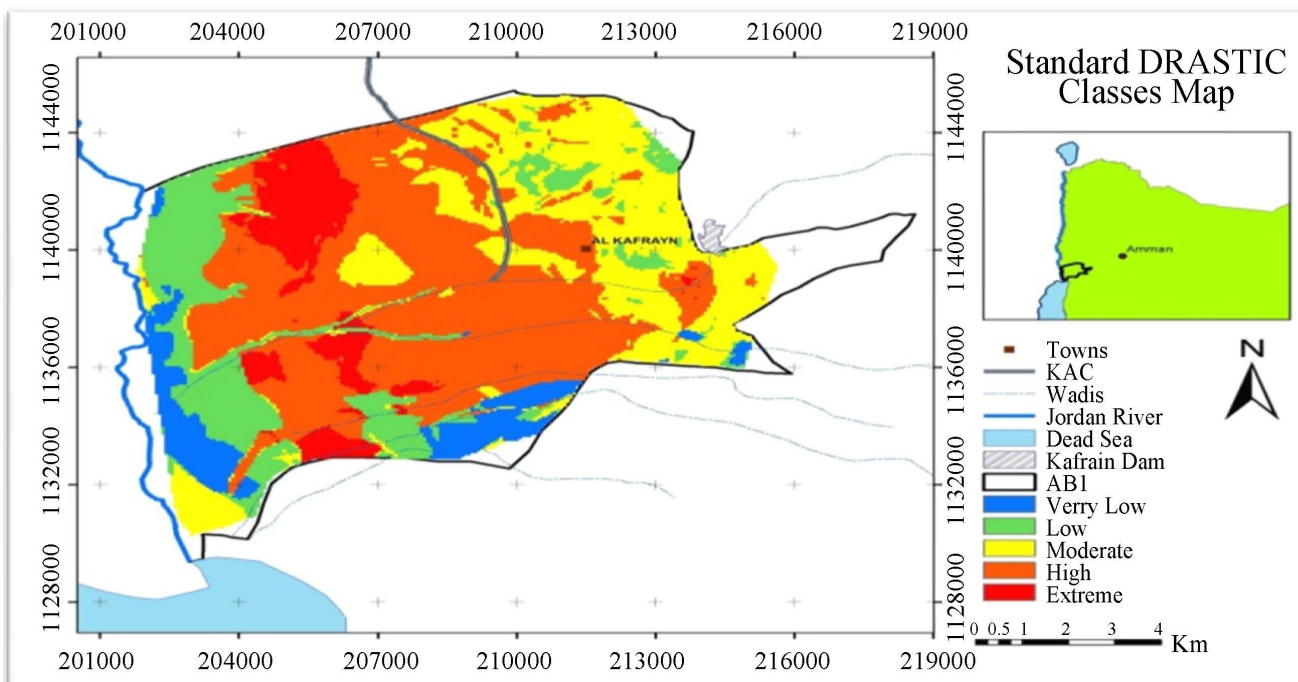

Figure 9. The vulnerability map. 
Table 1. Percent of each vulnerability class derived from attribute table of vulnerability map.

\begin{tabular}{ccccc}
\hline Value & Vulnerability Class & Count & Percent of Total Area (\%) & ${\text { Area in } \mathrm{Km}^{2}}^{2}$ \\
\hline 1 & Very Low & 1970 & 7.13 & 10.33 \\
2 & Low & 4439 & 16.1 & 23.29 \\
3 & Moderate & 7094 & 25.66 & 37.21 \\
4 & High & 11,655 & 42.16 & 61.14 \\
5 & Extreme & 2484 & 8.98 & 13.03 \\
Sum & & 27,642 & & $145 \mathrm{Km}^{2}$ \\
\hline
\end{tabular}

vulnerable to pollution from multiple sources.

\section{Conclusion}

In this paper, the vulnerability to pollution of the area between Wadi Shueib and Dead Sea in the Jordan Valley (AB1) subsurface basin was assessed and evaluated using raster calculations and the DRASTIC model for imaging maps. The assessment of vulnerability in the AB1 Subbasin in the middle of the Jordan Valley was accomplished by applying the empirical model index. The hydrogeological situation of the AB1 Subbasin is presented based on the seven DRASTIC model factors, which include: Depth to water, net Recharge, Aquifer media, Soil media, Topography, Impact of vadose zone and Hydraulic Conductivity. The seven variables were created and categorized and encoded employing various map and GIS function. They were evaluated by two numerical indexes, one referring to rating and one referring to weight. The vulnerability variables were characterized depending on a fixed interval of area percentage. The vulnerability index arguments were grouped into 5 categories, which were very low, low, moderate, high and extreme vulnerability. The colour codes are assigned to the percentages of pixels where the blue colours indicate very low vulnerability, the green colour indicates low vulnerability, the yellow colours indicate moderate vulnerability, the orange colour indicates high vulnerability, and finally red indicates extreme vulnerability. This paper concludes that the ABI Subsurface was categorized by high vulnerability classes while the middle and western parts were categorized by high to extreme vulnerability classes. The southern part of the AB1 displayed low aquifer vulnerability. The vulnerability map shows the high risk suffered by the middle and western parts of the AB1 Subbasin due to the high possibility pollution of intensive fruit and vegetable cultivation. In the AB1 Subbasin, land use and agricultural activities seem to be a good predictor of groundwater pollution by $\mathrm{NO}_{3}$ and some phosphor-organic pesticides.

\section{References}

[1] Ckakraborty, S., Paul, P.K. and Sikdar, P.K. (2007) Assessing Aquifer Vulnerability to Arsenic Pollution Using DRASTIC and GIS of North Bengal Plain: A Case Study of English Bazar Block, Malda District, West Bengal, India. Journal of Spatial Hydrology, 7, 101-121.

[2] Ettazarini, S. (2006) Groundwater Pollution Risk Mapping for the Eocene Aquifer of the Oum Er-Rabia Basin, Morocco. Environmental Geology, 51, 341-347. http://dx.doi.org/10.1007/s00254-006-0330-1

[3] Babiker, I.S., Mohamed, M.A., Hiyama, T. and Kato, K. (2005) A GIS-Based DRASTIC Model for Assessing Aquifer Vulnerability in Kakamigahara Heights, Gifu Prefecture, Central Japan. Science of the Total Environment, 345, 127140. http://dx.doi.org/10.1016/j.scitotenv.2004.11.005

[4] Lillesand, T.M., Kiefer, R.W. and Chipman, J.W. (2004) Remote Sensing and Image Interpretation. 5th Edition, John Wiley \& Sons Ltd., Hoboken.

[5] Royal Geographic Center (2005) Topography Map.

[6] Wu, Y., Wang, W., Toll, M., Alkhoury, W., Sauter, M. and Kolditz, O. (2011) Development of a 3D Groundwater Model Based on Scarce Data: The WadiKafrein Catchment/Jordan. Environmental Earth Sciences, 64, 771-785. http://dx.doi.org/10.1007/s12665-010-0898-3

[7] Aller, L., Lehr, J.H., Petty, R. and Bennett, T. (1987) DRASTIC: A Standhrdized System to Evaluate Ground Water Pollution Potential Using Hydrugedlugic Settings. U.S. Environmental Protection Agency EPA/600/2-87-035, 622 p.

[8] Shirazi, S.M., Imran, H.M. and Akib, S. (2012) GIS-Based DRASTIC Method for Groundwater Vulnerability Assess- 
ment: A Review. Journal of Risk Research, 15, 991-1011. http://dx.doi.org/10.1080/13669877.2012.686053

[9] Samake, M., Tang, Z., Hlaing, W., Innocent, N.D.O.H., Kasereka, K. and Balogun, W.O. (2011) Groundwater Vulnerability Assessment in Shallow Aquifer in Linfen Basin, Shanxi Province, China Using DRASTIC Model. Journal of Sustainable Development, 4, p. 53. http://dx.doi.org/10.5539/jsd.v4n1p53

[10] El Hanini, A., Added, A. and Abdeljaoued, S. (2013) A GIS-Based DRASTIC Model for Assessing Phreatic Aquifere of Bekalta (Tunisian Sahel). Journal of Geographic Information System, 5, 242-247. http://dx.doi.org/10.4236/jgis.2013.53023 
Scientific Research Publishing (SCIRP) is one of the largest Open Access journal publishers. It is currently publishing more than 200 open access, online, peer-reviewed journals covering a wide range of academic disciplines. SCIRP serves the worldwide academic communities and contributes to the progress and application of science with its publication.

Other selected journals from SCIRP are listed as below. Submit your manuscript to us via either submit@scirp.org or Online Submission Portal.
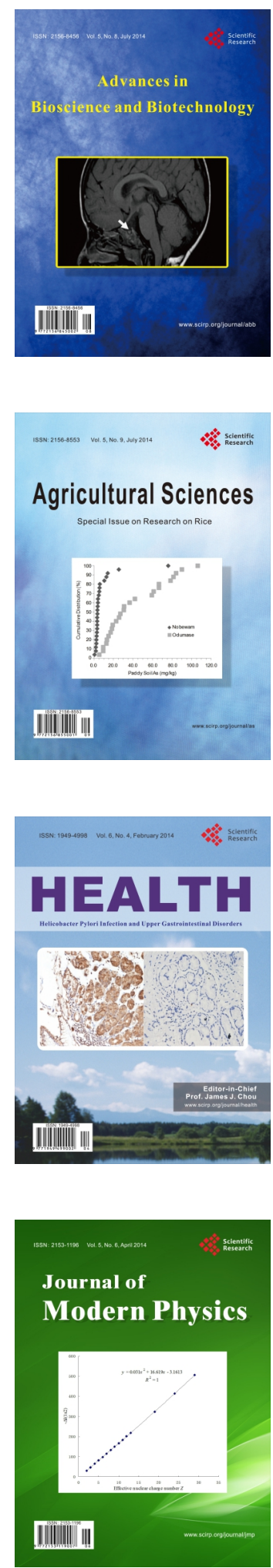
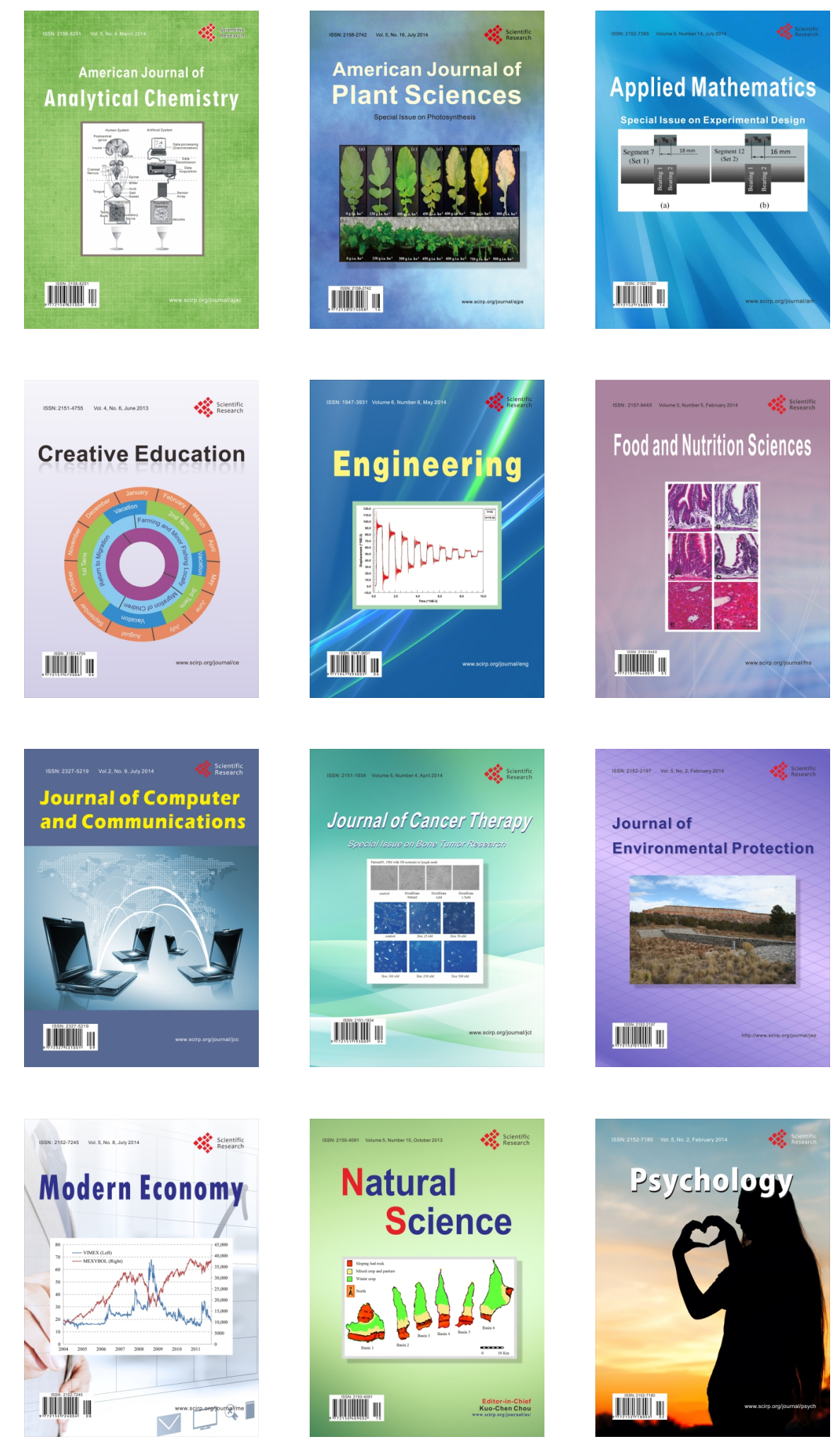